\title{
Children's Rights, Parental Agency, and the Case for Non-coercive Responses to Care Drain
}

\author{
Anca Gheaus
}

\section{Introduction}

Worldwide, a large number of people migrate in order to take up temporary employment. Of those who have children, many cannot afford to bring them along and must, therefore, leave them in their country of origin. Thus, much temporary, years-long migration results in the separation of parents and children. This is a morally challenging situation. On the one hand, there is a widespread belief that children need continuity in care. That is, they need parental affection and guidance throughout their childhood. According to international conventions, children have a right ${ }^{1}$ to proper parenting. By "parents," throughout this article, I refer to social parents, that is, to the people who play the parenting role in children's lives, rather than to biological parents, that is, to the people who bring children into existence. The claim is therefore not that biological parents are best suited to ensure the well-being of their children and the protection of their rights. Rather, the claim is that, once the parenting relationship is established-whether via procreation or adoption-continuity in parenting is integral to children's well-being. Furthermore, a certain degree of regular physical presence is necessary in order to ensure affection and guidance. And, finally, it is generally accepted that parents bear a special responsibility to ensure their children's well-being; only if parents fail to discharge this responsibility are other agents,

I am grateful to Diana Meyers for comments on an earlier draft. While writing this paper I have benefited from a De Velling Willis Fellowship at the University of Sheffield. 
such as state institutions or the wider community, obligated to take responsibility for children. Migrating without one's children is, therefore, problematic.

On the other hand, much of the temporary migration is driven by poverty; unemployed or underemployed parents migrate in the hope to secure necessary work. It is also widely believed that people have a moral right to seek the fulfilment of their basic material needs, and, independently from this, a right to mobility. Moreover, one of the key motivations for migration, according to migrant parents' own testimony, is to be able to discharge their parental duties concerning their children's material well-being. Children have a right not only to continuity in care but also to proper nutrition, housing, and education, and at least some of the migrating parents are driven by their inability to ensure these in their country of origin.

There are, therefore, important moral reasons both for and against parents' migration. Since some of these reasons concern rights, and states have the responsibility to ensure that their citizens' rights—whether children or adultare not violated, parents' migration is a political as well as an ethical issue.

In an ideally just world, the conflicts at stake could be avoided: between children's rights to material well-being on the one hand and to continuity in care on the other hand; and between parents' right to economic security and mobility on the one hand and their responsibility to provide continuity in care on the other hand. I assume that in such a world individuals would have at least the sufficient level of material resources necessary to ensure their own and their dependants' well-being. ${ }^{2}$ Ideally, adults would generally not need to migrate for economic reasons. And if they needed to migrate in exceptional situationsdue, for instance, to natural disasters - they would have the legal and material means to take their children with them. Yet such a world is unfortunately far from sight. Actually existing societies continue to be tarred by poverty. Some efforts are being made to allow migrant workers to bring their children along but we are far from effectively enabling all temporary migrants to do so. ${ }^{3}$ These structural limitations are likely to continue for a long time, and, while trying to address them, we need temporary institutional solutions to ensure that children's rights to both material and emotional care are respected.

This paper has two closely related aims. First, it addresses the questions of parents' moral entitlement to migrate without their children in spite of the importance of parental continuity for children's well-being. It explains why parents who must choose between poverty and migration suffer from a form of impaired agency and are not therefore to be blamed for imposing on their children years-long separation. The second aim is to discuss the best ways of addressing the conflicts of rights and responsibilities described above in 
non-ideal social circumstances. Legally restricting parents' migration unless they take their children with them would be illegitimate. We should rule out coercing parents to either not migrate or else migrate together with their children. This, however, does not mean that states are justified to withdraw any responsibility with respect to migrants' children's emotional well-being, nor that it is enough for states to pass laws requiring parents to ensure legal guardianship for their children during absence. Instead, I argue that states should put in place programs of counseling, attached to schools and preschool caring institutions, whose role is to provide robust emotional support and guidance to migrants' children during their parents' absence. These programs can be funded using some of the money raised by taxing remittances, which in certain cases constitute a significant part of the sending countries' gross domestic product (GDP). This solution is therefore less coercive than restricting migration. It makes use of coercion only to the extent to which it relies on taxation of remittances and to the extent to which schooling itself is mandatory. Both taxation and mandatory schooling, however, are coercive means already employed by most states. Less coercive ways of addressing parenting deficits are, other things being equal, preferable to more coercive approaches-or so I argue. Finally, I will explain why this solution makes fair use of the migrants' remittances. Yet the argument is that states owe this remedial measure both to migrants' children - who are among the most vulnerable members of societyand to their parents as a form of restoring their agency; therefore, when the money raised from taxed remittances is not enough to fund proper counseling, other sources of funding ought to be sought.

This chapter is structured as follows. Section 2 expands on the reasons why the long-term separation between parents and children in the context of temporary migration, a phenomenon sometimes called "care drain," is morally problematic. Care drain negatively impacts on children's interest in continuity in care and, in some cases, on parents' moral agency. Care drain has been mostly discussed in the context of the feminization of migration. I assume that mothers and fathers are equally responsible for the continuity in care that ensures children's emotional well-being.

In the third section I first explore the more coercive responses to care drain. I argue that restricting migration for parents who are poor or at risk of poverty is illegitimate and legislative measures aimed at ensuring legal guardianship for children during their parents' absence are, by themselves, insufficient and likely to be inefficient. I then make the case for supplementing such legislation with counseling programs meant to ensure robust guidance and emotional support to the migrants' children. 
The primary illustrations of the various problems raised by care drain are taken from the case of Romanian temporary migrants, but I indicate that these examples generalize to temporary migration from other countries such as Poland, Mexico, Pakistan, and countries in Southeast Asia-and, sometimes, even to migration within the borders of the same large country, such as China (Qin and Albin 2010).

\section{Children's Rights and Parents' Agency in the Context of Care Drain}

\section{A. Care Drain}

Over the past few decades migration has become increasingly feminized-or at least, international women migrants started to show up in statistics in bigger numbers; in 2005 women represented half of the world's migrants (Morrison, Schiff, and Sjöblom 2008, 2). Female migration has also been receiving increased public-including scholarly-attention and much of this attention is directed to the effect of women's migration on the gendered division of labor in sending countries. Because in most societies women continue to be the main providers of care for dependent family members- not only children but also elderly parents and ill or disabled relatives-some scholars' attention has been drawn to the question of what happens when women start to migrate in higher numbers. The loss in hands-on care suffered by dependent family members left behind by migrant women is often referred to as "care drain" (see, for instance, Hochschild 2000; 2005). Care drain is said to consist mostly in migrants who move "in five main migratory streams-from Eastern Europe to Western Europe, from Mexico, Central and South America to the United States, from North Africa to Southern Europe, from South Asia to the oil-rich Persian Gulf and from the Philippines to much of the worldHong Kong, the U.S., Europe, and Israel" (Isaksen, Devi, and Hochschild 2008, 405). In this paper I leave on the side the contentious issues of whether it is fair to focus exclusively on women's migration in the study of care drain (Dumitru 201I argues it is not, and I discuss this in Gheaus 2013b) since my focus here is on responsibilities toward one group of dependents left behind: children. Both morally and legally, not only mothers but both parentswhether heterosexual or homosexual-bear the primary responsibility for their children's well-being. Hence, I talk about migrant parents rather than migrant mothers, thus bypassing the question of exactly what percentage of men's migration is responsible for care drain. 
People migrate for various reasons. My interest here is in those migrants who meet all of the following criteria: (a) are parents of minor children whom they leave at home; (b) migrate in order to work on a temporary basis (often leaving when they have a contract, which they then renew, or else find a new contract while already abroad); and (c) are mostly motivated by poverty, corruption, and structural unemployment or underemployment in their place of origin. Of course, some parents who are not poor or at risk of poverty also migrate without their children. The normative analysis I offer here is not meant to apply to this group. It is plausible to assume that migrants whose agency is not impaired by poverty or the threat of poverty are more capable, and hence more likely, to migrate together with their children; ${ }^{4}$ if they have this possibility and yet decide to separate from their children, and if as a result children suffer harm, these parents are likely to to bear moral responsibility for the harm.

I shall take turns discussing what moral rights children have and why continuity in parental care is important for their development, analyzing the harms inflicted on them by separation from their migrant parents, and arguing why the parents discussed here should not, nevertheless, be held responsible for this situation.

\section{B. Continuity in Care and Children's Moral Rights}

It is a truism that children need to be raised by grown-ups. Specifically, they need the care of committed and competent adults-adults capable and willing to take responsibility for their interests (which vary with age) and to foster their moral and practical agency. Without such care many children do not survive and those who do survive face great suffering and are less likely to flourish. As vulnerable, not yet fully autonomous human beings, who cannot be held responsible for their own existence and circumstances, children have a moral right to adequate care in order to protect them from harm and allow them to thrive.

One of the more contentious questions is whether the care owed to children should be given via parenting - that is, within an arrangement where a small number of adults are morally and legally responsible for every particular child's well-being over whom they exercise authority. Why is parenting better than bringing up children in well-run orphanages staffed with professional child minders or in communities such as the kibbutz? Such alternative childrearing arrangements could avoid some of the undesirable consequences of parenting: most prominently, its tendency to unfairly disrupt social equality 
(Rawls 1972; Blustein, 1982; Munoz-Darde 1999). Yet philosophers-like everybody else-tend to agree that parenting is the best way of raising children. A few philosophers (such as Narveson 2002) believe the justification of parental rights comes exclusively from parents' own interests and their proprietary relationship to their biological offspring. But most philosophers legitimize parenting by appeal either to children's own interests alone, or to a combination of children's and parents' interests, which dictate that children ought to be raised by parents (Blustein 1982; Clayton 2006; Brighouse, and Swift 2006; Archard 2010). ${ }^{5}$ And the main reason for children having parents rather than more or less transitory caregivers is children's interest in being loved and cared for by someone who is there for them during their entire childhood.

Here I assume that continuity in care requires the frequent and regular presence of parents in their children's lives, and that some degree of physical presence is also necessary for continuity in care. ${ }^{6}$ One may care about another person without providing any direct help with meeting that person's needs, and "caring about" may be very valuable for the recipients. Yet parents' importance in children's lives comes largely from them also caring for the children. (For the classical distinction between "caring about" and "caring for," see Tronto 1993.)

Before I go on to analyze children's interest in continuity in care, let me note that international documents protecting children's rights also recognize the importance of continuity in care. The United Nations Convention on the Rights of the Child (United Nations 1989) stipulates that only the child's best interest can justify the separation between a child and her or his parents against the parents' will (Article 9.I) - thus acknowledging, implicitly, that the child's interest in continuity in care can be trumped by other considerations (presumably, parental neglect or abuse.) Yet unless such special circumstances apply, parents and children have a right not to be separated. When physical separation is unavoidable, "States Parties shall respect the right of the child who is separated from one or both parents to maintain personal relations and direct contact with both parents on a regular basis, except if it is contrary to the child's best interests" (Article 9.3). Finally, in cases when children need adoption or fostering, the CRC stipulates that " $[\mathrm{w}]$ hen considering solutions, due regard shall be paid to the desirability of continuity in a child's upbringing" (Article 20.3).

Why is continuity in care so important to children's well-being? According to Anne Alstott, adequate parents are both nurturers and advocates of their child until she or he reaches maturity (Alstott 2004, I6), and their 
continuous relationship with the child uniquely qualifies them in these capacities. Thanks to the long-term direct involvement with their children, parents acquire a depth of knowledge and psychological identification with the well-being of the child. Neither adequate knowledge nor psychological identification is possible in shorter-term relationships. For the claim that children's psychological well-being requires continuity in care, Alstott relies on the work of child psychologists such as Anna Freud, Albert Solnit, and Joseph Golstein. Their by-now classical theories of child development see disruptions in continuity in care as a possible source of psychological trauma for the children. At different ages, continuity in parental care is important for different reasons. For instance, "during the rebellions of adolescence, parents offer a stable relationship, permitting the child to experiment with rejection and distance without rejecting the child in return" (Alstott 2004, 17).

The second claim is that continuity in care in also important for social reasons; parents act as an interface between their children and the larger society, and their knowledge of the child makes them the best advocates of children's interests (Alstott 2004, I8). Indeed, parents are also supposed to legally represent their children's interests and make sure that their rights are being protected.

What happens then in the situation in which migrant parents, who cannot take their children with them, are absent for extended periods-sometimes months or years at a time $?^{7}$ To the extent to which children are attached to their migrant parents, they are bound to experience loss even if other, reliable, adults step in to take over their care. Perhaps the most straightforward way to explain it is that children become emotionally attached to their parents and, in general, people are non-fungible to the ones who love them. This is how non-fungibility is to be understood: "If an object having import to you is such that its being taken away ought to be experienced as a loss regardless of the state of other objects that might have or come to have import to you, then...that object has non-fungible import" (Helm 2010, 200). Parents are usually non-fungible to their children, which means that even if other competent and loving adults were to reliably take over the hands-on care of the migrants' children, children would be bound to experience loss.

Yet according to studies from different countries, the caring arrangements put in place for migrants' children are not always stable. Caring responsibilities are sometimes chaotically allocated, with various relatives and neighbors taking over, sometimes leaving children growing up on their own. Studies indicate that, for instance, in Romania, about thirty-five hundred children with migrant parents are cared for by neighbors, friends, or minor siblings 
(UNICEF and AAS 2008). ${ }^{8}$ Even when children remain in the care of a family member-most likely female, often a grandmother (for Romania, see Piperno 2007a; 2007b) — care arrangements tend to be unstable due to difference in age between children and grandparents, the overburdening of the person who takes over the caregivers' role, and the necessity to relocate the child (for instance from a city to the countryside) (Pantea 2012; 2013). Research on Polish migrants' children also indicates that caring arrangements for migrants' children can be unstable (Lutz and Palenga-Mollenbeck 2012). This may or may not generalize across the board, but many parents who migrate work in relatively precarious employment as seasonal agricultural laborers, workers in construction, or caregivers in private homes. It is plausible that they lack the ability to plan ahead: they need to seize job opportunities at short notice and cannot know if they will be able to find a new contract once they emigrate. Some parents have to leave without even giving proper warning to their children (Piperno 2007a).

Private arrangements for providing care to migrants' children seem insufficient for many of them: first, because even when they work well, children suffer the loss of parental continuous care; and second, because depending on particular contexts, the care arrangements may be unstable. This is more true for children growing up in nuclear families than for those raised in extended families where the contrast between primary caregivers (parents) and other adults is likely to be less sharp. The case for the state supplementing migrant children's care with counseling programs is weaker or stronger depending on how much continuity in care particular children already experience-for instance, are they being looked after by a grandparent who was already closely involved in raising the child before the parents' migration, or is their care taken over by a previously distant relative? Similarly, there is a stronger case for offering these services to children whose care arrangements, post migration, are less stable.

To sum up, years-long separation between children and their parentsdefined as their primary caregivers-in the context of temporary migration harms children's strong interest in continuity in care. Children have a right to adequate levels of care, and there are good reasons to believe that continuity in care is a constitutive element of children's well-being. In particular, continuity in care is essential to their emotional and developmental well-being.

The above claim is compatible with the fact that the overall impact on children of their parents' migration is both complex and disputed (see sources cited in Lutz and Palenga-Mollenbek 2012; Jordan and Graham 2012). 
Thanks to remittances, migrants' children-just like other family membersare materially better off than before migration and sometimes better off than children whose parents do not (need to) migrate. The money sent by their migrant parents buys them better food, accommodation, and education, but sometimes also functions to single them out among their peers, and even ostracize them (AAS 2006; Piperno 2007a; Isaksen, Devi, and Hochschild 2008). School performance and social behavior sometimes are and sometimes are not negatively affected (Kandel 2003; AAS 2006; SFR 2007; Jordan and Graham 2012).

But children from various parts of the world, who are separated from their migrant parents, do tend to report feelings of loss and betrayal, higher levels of depression, anxiety, and sheer unhappiness (AAS 2006; SFR 2007; Piperno 2007a; UNICEF and AAS 2008; Isaksen, Devi, and Hochschild 2008; Farooq and Javed 2009; Qin and Albin 2010), and sometimes even "guilt for the sacrifice made by their mothers" (Piperno 2007a). Separation in the context of temporary migration is not only introducing discontinuity in parental care but also, very probably, disrupting primary caring relationships. Research on migrants' children in Southeast Asia indicates that children of migrant parents, especially migrant mothers, are less likely to be happy compared with children in non-migrant households (Jordan and Graham 2012). Finally, children's relationships with the migrating parent and with the custodial parent sometimes deteriorate under the pressure of ad hoc, unclear allocations of caring responsibilities (SFR 2007; Pantea 2012).

Because migrants' children sometimes end up materially better off than otherwise similarly situated children whose parents do not migrate, and because remittances are used to fulfill some of their fundamental interests such as housing and education, sociologists are often reluctant to claim that migration harms the children. (By contrast, psychologists and educators quoted by studies on care drain usually deplore the effect of parental absence on children.) Are better education and proper housing more or less important than continuity in care? I avoid giving an answer to this question because I rely on a non-comparative account of harm (Shiffrin 1999), according to which one is harmed if one has a fundamental interest frustrated even if the action that frustrates the said interest is necessary for avoiding even greater harm. In other words, if children have a right to adequate care then they have a right to both necessary material means and continuity in care, and if a systematic and large-scale phenomenon such as temporary migration is frustrating their interest in continuity in care, they are being owed reparation. 


\section{Parents' Agency}

Who, then, is responsible for making sure that children do not suffer too large disruptions in continuity in care and, when disruptions are unavoidable, that children are helped to mitigate the negative emotional and developmental effects of separation from their parents?

One plausible answer is that migrant parents themselves are responsible for any frustration of their children's fundamental interests that result from parental migration. I argue that this answer is incorrect, at least in the case of those migrant parents I consider in this paper.

The prima facie plausibility of this answer comes from the fact that, in general, parents are the primary bearers of responsibility for the child's well-being. It is commonly believed that parents have the duty to make sure that their children's interests are being met and only in cases when they cannot do this is the responsibility transferred to other agents such as, for instance, child protection agencies. There is a debate about the content and the extent of what is owed to parents to help them meet their duties toward their children and/or to compensate them for the costs in time, income, and autonomy they incur in the process of childrearing. However, one of the reasons why it is legitimate for parents to have extensive rights over their children, rights they exercise to the exclusion of other adults, is that adequate childrearing requires designated bearers of responsibility for each individual child. Without allocating responsibility for individual children to individual adults, we would face a serious problem of coordination in the discharging of duties that adults as a group have toward children as a group (Goodin 1985). Moreover, some believe that parental responsibility makes an important contribution to parents' own well-being and is therefore a constitutive part of the content and justification of parental rights (Brighouse and Swift 2006). The standard exception to the rule that parents bear primary responsibility for their children's well-being is when parents cannot discharge their responsibility properly. One example is when parents do not have the means for ensuring their children's well-being-for instance, when they are too poor to do so-cases in which we believe that state institutions are called to step in and take charge for the unmet interest of the child. Another example concerns cases of child abuse and neglect. In these cases it may be legitimate for states to withdraw some or all parents' rights with respect to their children and seek to allocate them to individuals who would make adequate parents.

One may argue that it is the migrants' own duty to do all they can such that their children enjoy continuity in care; this means either not to migrate 
or else to find a way to take their children with them. If so, the argument would go, parents who migrate without their children are to be held responsible for their children's fate. Parental migration, according to this view, is a form of parental abandonment.

This position is too harsh on migrant parents. Instead, it seems plausible that parental migration under circumstances of poverty or threat of poverty is more like situations when parents are unable to fulfill some of their children's fundamental interests. In the latter cases the proper response is not moral blame and the withholding of custody but the provision, via state institutions, of what is necessary in order to fulfill the child's needs.

Many parents engage in temporary migration because they feel trapped in poverty or threatened by poverty. They come from regions where there is structural unemployment or underemployment and/or from countries with endemic political corruption that makes improvements in labor markets unlikely in the short run. According to their own testimony, many parents migrate in the hope that they will be able to save sufficient money to provide basic goods such as adequate housing and education for their families left behind. So part of their motivation to migrate is a desire to meet their children's interests other than in continuity in care, interests that are their responsibility to meet.

True, international migrants are not likely to be the very worst off in their society: successful work migration presupposes some education, social connections, and starting capital. Yet not only poverty but also the threat of poverty is morally relevant; many temporary migrants come from countries plagued by corruption and with weak and continually degrading welfare states-Romania is an example of both (Piperno, 2007c; Dobre 2009). Both features impose on citizens risks such as unpredictably losing their jobs and finding themselves without healthcare and social security should they need it. Under such circumstances, the wealth one accumulates in the form of home ownership and savings can function as insurance against such risks. People who lack this security suffer a form of disadvantage even if they are not among the poorest citizens, because the imposition of high risks is itself a form of disadvantage (Wolff and De-Shalit 2007).

In the next section I argue that temporary migrants' poverty and the threat of poverty are relevant to what states owe them qua parents and to their children. But poverty and the threat of poverty are also relevant to judging parents' responsibility for imposing discontinuity in care on their children. Moral responsibility presupposes a kind of moral agency that poverty and insecurity undermine. Parents who migrate under these circumstances have a 
limited form of agency qua parents because they lack full moral autonomy as well as truly voluntary choice.

Seana Shiffrin has argued that full moral autonomy is disrupted by situations of choice in which people lack a range of morally permissible options to choose from (Shiffrin 1991). Parents who contemplate migration due to poverty or serious uncertainty are in precisely this situation, because at least one of the options they face-and, arguably, both - is morally objectionable. Leaving their children behind means to impose on them discontinuities in care. Foregoing the possibility to migrate is clearly a prudentially problematic choice, if not migrating means to continue a life of poverty and/ or uncertainty so that they will be unable to ensure the material basis for their and their family's living. And since parents bear special responsibility for their children's well-being, the latter option is also morally problematic: the parents who forego migration also forego the prospect of decent accommodation, education, and so forth for their children.

Poor parents, or parents who are seriously threatened by poverty, also lack voluntary choice with respect to migration. On Serena Olsaretti's analysis, a choice is voluntary if and only if it is not motivated by a lack of acceptable alternatives (Olsaretti 2004; 2008). Not migrating, and thus failing to ensure decent living conditions for oneself and one's family, is hardly an acceptable option. This makes the migration of parents who are poor or threatened by poverty not fully voluntary and hence not autonomous.

What about parents who migrate without their children even if they could find reasonable employment in their place of origin, or else if they had a reasonable prospect of taking their children with them while making migration financially worthwhile? Presumably, not all migrant parents' agency is impaired by poverty and/or insecurity to the level that would deem them not morally responsible for the harms incurred by their children who remain behind. ${ }^{10}$ While these parents are not the focus of this paper, the policies advocated for the sake of children whose parents migrate out of lack of acceptable alternative will apply to all children separated from their migrant parents. This, I assume, is justified pragmatically, since policies cannot be sufficiently fine-grained to address each case on its merits. Moreover, even if some migrant parents are guilty of child abandonment, it does not necessarily follow that the best reaction is to withdraw their parental status and the rights over children that come with this status. Many think states should be very cautious about withdrawing parental rights and thus legally separating parents and children. The bond between parents and children is sufficiently important to children to make it difficult to judge whether the child's interest is 
better served by legal separation from the parents or by enabling the parents to keep their parental status while trying to help the child in those respects in which parental care has failed (Brighouse and Swift 2006; Macleod 2013).

Finally, it would not be fair to morally condemn migrant parents for having decided to become parents in the first place. First, in many parts of the world procreation is not a voluntary or fully voluntary choice. Second, most people presumably decide to parent in the reasonable hope that they will have adequate means to raise their children themselves; some parents become unable to do so after having become parents-for instance, because they lose their jobs and have to consider migration. Finally, and perhaps most important, it has been argued that raising a child is a fundamental interest, powerful enough to ground a moral right to parenting (Clayton 2006; Brighouse and Swift 2006). If this is correct, then it is unfair to expect people to give up parenting because they are too poor or threatened by poverty, especially through no fault of their own. If adults who have the psychological and social skills that enable them to parent adequately have a moral right to raise a child, then fairness seems to require that they be given access to the material conditions for doing so.

To conclude this section, children's powerful interest in continuity of care is inevitably hurt by the temporary migration of their parents. Many of the parents cannot be held responsible for this fact, and therefore states should take responsibility for the children's emotional and developmental well-being, which is the most likely type of harm they suffer as a result of their parents' migration. What are states to do?

\section{Policy Responses to Care Drain}

\section{A. Coercive Solutions}

States can, and some do, adopt coercive approaches meant to ensure the well-being of migrants' children. One example is Romania, which passed a law requiring parents to make legal arrangements for the guardianship of the children who remain in the country of origin (Pantea 2013). Coercive policies, which do not allow parents to migrate without having arranged proper custody for the children left behind, can be implemented, for instance, by requiring migrants, when they cross the border, to prove they registered their children with appropriate authorities. And states can impose sanctions on migrants, such as significant fines if migrants are caught in an irregular situation or even the withdrawal of parental rights. Similar coercive measures restricting the migration of a certain class of citizens-interestingly, also 
motivated by the need to ensure sufficient care in the country of origin-are not unheard of. Many countries face a dramatic shortage of healthcare, which is partly caused by the massive migration of doctors and nurses. They try to address this by limiting the migration of healthcare staff-for instance, by requiring them to serve a number of years in their home country before being allowed to migrate, withholding practice licenses, and/or imposing prohibiting fees on defaulters. (For numerous illustrations, see Frehywot et al. 20 Io. And for a lengthy helpful discussion of the legitimacy of such policies, see Stanczyc 2012.)

This potential approach to mitigating the effects of care drain suffers from three problems: it is, at least in some countries, inefficient; it does not solve the problem of ensuring continuity of care for migrants' children; and it is illegitimate. Below I examine each of these problems.

According to Pantea (2013), the efforts of Romanian authorities to ensure proper custody for the children left behind has been "[n] otoriously unsuccessful, with only seven per cent of the migrant parents officially entrusting their children to members of the extended family" and "the requirement became a binding law in $201 \mathrm{I}$ with apparently not much change following its initiation" (Pantea 2013, 160). The explanation may lay in several facts about temporary migration that are not likely to change in the near future: First, many parents do not know in advance for how long they are going to be abroad; they leave with or without a contract, hope to renew their contract if they have one and/or to find a new job when the first one ends. Second, as I state earlier, many parents are obliged to leave on extremely short notice, and they do not have time to arrange legal custody for their children (Piperno 2007a). To the extent to which these facts about temporary migration generalize, laws meant to ensure legal custody for migrants' children are likely to be inefficient. Parents may prefer to risk fines than miss precious job opportunities, and states are unlikely to be able to suspend the parental rights of large numbers of migrants.

Moreover, coercive approaches to care drain — short of very drastic onesfail to address the biggest problem, which is discontinuity in parental care. Parents may be required to arrange legal guardianship, but this does not in itself fulfill the children's emotional and developmental interest in parental care, for the guardians may be irresponsible or unloving. The more drastic measures of banning parents' migration are likely to affect negatively other fundamental interests of children, those in the material bases of a decent life. And legally requiring migrants to take their children with them would be in most cases economically, or otherwise, unfeasible. Finally, if sanctions are 
imposed on parents who fail to respect the law, such as imposing fines or withdrawing parental rights, it would ultimately hurt the interests of those children whom the laws were meant to protect in the first place.

The most important problem with coercive approaches to care drain, however, is that they are illegitimate, because they put too much of the burden of the choices concerning migration on parents. As I discuss above, many parents migrate because they are poor or threatened by poverty and most are motivated to migrate by the desire to meet their children's interests other than in continuity of care. To prevent them from migrating without having ensured proper custody arrangements for their children means, in practice, to prevent them from migrating when work opportunities arise. If the analysis according to which migrant parents' agency with respect to migration is impaired by poverty or threat of poverty is correct, then to prevent them from migrating implies limiting their possibilities for future agency. For parents who are poor or threatened by poverty, mobility and the quest for more adequate working conditions are a means of seeking an economically better future when they can meet all their parental responsibilities-either by returning home with enough savings or else bringing their children to their country of destination, in case they settle down there.

\section{B. Non-coercive Solutions}

The better approach is to encourage migrants to regulate their children's custodial situation without preventing them from migrating in case they fail to do so and, at the same time, try to mitigate the harm that discontinuity in care inflicts on children. These desiderata can be accomplished through two types of program. First, efforts should be made to educate potential temporary migrants about the importance of stable, well-planned care arrangements for their children and proper advance communication about the possibility/likelihood of migration. Second, state agencies should give children-and, possibly, their families - access to state-funded counseling services meant to help the children understand their parents' absence and cope with their feelings of depression, betrayal, guilt, and sheer loss. Children can be reached by attaching the counseling programs to the child care institutions that children attend anyway — such as school—and, for preschoolers and children who do not attend school, via local communities. Counseling services for children could be easily funded, in many of the countries that send migrants, by using some of the taxes on remittances. According to Dayton-Johnson et al., economists in global institutions like the World Bank think that remittances 
sent by migrants from Third World countries constitute a significant source of income and development (Dayton-Johnson et al. 2007). The same holds true for some European countries from the former Soviet bloc, such as Romania where remittances in 2006 reached $€_{4.8-5.3}$ billion (HIIE 2007). Hence, it would take a small fraction of the taxes raised on remittances to ensure that all children have easy access to as much counseling as they need in order to minimize the harm of discontinuity in care.

The approach I suggest does a better job than coercive approaches. Although it cannot address directly children's interest in continuity in care, it tries to rectify the harms of separation. It is also more likely to be efficient: the non-compulsory nature of counseling is likely to make it more appealing, and so effective since no message of parental incompetence or blameworthiness is being sent. Indeed, existing studies in Romania show that educators, schoolteachers, workers in child protection agencies and in nongovernmental organizations that focus on children's well-being all agree that additional monitoring and counseling services are necessary to mitigate the harms entailed by discontinuity in parental care in the context of migration (AAS 2006; UNICEF and AAS 2008; SFR 2012).

I dedicate the rest of this section to explaining why the approach to care drain that I advocate is also legitimate. To start with, a non-coercive solution to care drain that aims to compensate children for their loss of continuity in care does right by children. Unlike restricting parents' migration, it does not deprive children of the welfare benefits that follow from their parents' migration. And unlike a mere requirement that parents legalize their children's custodial arrangements, it acknowledges that a central problem to be solved is that of the emotional loss entailed by separation. It also acknowledges parents' limited agency in the place of origin, and it is more likely to enhance their future agency as I explained in the previous section.

Reasons of distributive justice also recommend this approach. Feminists have long argued that economic justice should take into account the universal interest that we all have in care during the vulnerable periods of our lives. For example, Daniel Engster (2008) defends an understanding of economic justice according to which an economically just society ensures that all individuals are able to care for themselves and their families. According to Engster, a central motivation for working-one shared by the majority of people - is to be able to care for oneself and one's dependents. Therefore, an economic system that fails to enable most citizens to provide necessary care is deeply objectionable. Engster identifies several goals of economic justice: the promotion of sufficient prosperity to allow all people to meet their biological 
and developmental needs; a fair distribution to ensure that the economic resources are actually used for meeting the relevant needs; and the support and accommodation of direct care services and personal caring activities, for instance by making possible for parents to combine work and childcare. This conception of an economically just society requires that all individuals should have access to jobs remunerated well enough to allow them to care for themselves and their dependents. Moreover, jobs should not systematically interfere with workers' ability to care, and governments should ensure that enough caring services are available.

To the extent to which countries of emigration do have the necessary resources that could ensure the meeting of all their citizens' important interests, but fail to accomplish this goal either due to corruption or to mismanagement or to unjust distributive institutions, they are ultimately responsible for the predicament of migrant parents and their children. However, some of the sending countries may indeed be too poor to ensure that all their able-bodied citizens can earn wages adequate for supporting themselves and their families, or else that they receive adequate material support from the state. It does not follow, however, that in such cases considerations of background distributive injustice are irrelevant to the treatment of migrants and their children. Various strands of cosmopolitanism (Blake 2005) in thinking about global justice all hold that an individual's place of birth is morally irrelevant and hence should not negatively impact her or his access to advantage (whether advantage is defined as resources, opportunities, capabilities, etc.). If sending states are poor, but distributively just, then those institutions that keep in place unjust distributions at the global level are responsible for the migrants' predicament. In either case, given the current level of technological development that should make possible the satisfaction of important needs on a global scale, it is very implausible that migrants and their children's predicament is the kind of situation for which no one can be held responsible.

It is worth emphasizing that migrant parents and their children have a claim of justice to resources in the form of public institutions able to address the emotional and developmental challenges of separation. In places where the welfare state has been shrinking, it is sometimes denied that migrants and their children are entitled to limited, state-funded child care resources in general-let alone to specialized counseling services. Some societies even doubt the former type of entitlement on the grounds that migration is a free choice. For instance, in Poland there is a "heated discussion about whether migrant children were entitled to placement in day-care. As the number of these care facilities is insufficient, single parents are now privileged when 
applying because they are considered to have a justified claim to preferential treatment. In contrast, single parents in migrant families are considered fragmented 'on their free choice and should bear the consequences of their decisions' - as the head of one kindergarten stated" (Lutz and PalengaMollenbeck 20I2, 28). Of course, this argument is flawed since, whatever the parental responsibility for migration, it is unjust to deny necessary care to children. But, as I argued, parental choice to migrate is in many cases not fully voluntary and autonomous. Moreover, impaired agency, which is in itself regrettable, is imposed on parents by states' failures in distributive justice-at least in cases where parental poverty is caused by corruption or deficient administration - rather than by scarcity of resources tout court.

\section{Notes}

I. In this paper I use "right" to refer to legal rights—in most cases, to rights inscribed in international legal documents such as the United Nations Convention on the Rights of the Child. On the few occasions when I refer to a moral right, I specify the qualification. Also, I develop my reasoning in terms of children's needs and fundamental interests, rather than moral rights. I do so in order to emphasize that mine is a moral, rather than legal, argument. Like other philosophers (Brighouse and Swift 2006) I believe that the interest theory of moral rights is correct, and that it is the only theory of moral rights that can make sense of the idea that children have moral rights.

2. One of the central debates in theories of distributive justice is whether resources or well-being should be distributed according to a principle of equality, priority toward the worst off, or sufficiency. Sufficiency is the least demanding of the three; thus, in a more egalitarian society parents would have even less material need to migrate than in a sufficientarian society.

3. One of the reasons why migrating together with one's children is currently infeasible for temporary-work migrants is also economic: even if the countries of destination would take responsibility for the healthcare, daycare, and education of migrants' children, bringing children along may make it impossible for migrants to save enough to be able to return to their countries with a better economic situation.

4. I leave out of my analysis parents who flee their homes due to war and political, religious, or racial persecution. Sometimes they may also be unable to take their children with them; these are tragic cases in which the migrants' (and presumably, their children's) links of citizenship with their own states are deeply severed. This also complicates the question of who should take responsibility for the children left behind by migrants in these circumstances.

5. Though not necessarily by two parents. Three-parent families started to appear as a matter of practice and, recently, to gain some legal recognition. For defenses of the virtues of three-parent families, see Cutas (20II) and Brennan and Cameron (manuscript). 
6. In Gheaus (2013b) I explain why this requirement is not likely to be met in the context of long-distance migration. The requirement of regular and frequent physical presence is not incompatible with children spending substantial amounts of time in nonparental care-indeed, it seems that non-parental care, when supplementing parental care, is generally beneficial to children (Waldfogel 2006). Increasing numbers of migrants use phone and teleconference in order to keep regular contact with their children-sometimes even to supervise their homework from a distance. I assume that, while this form of communication goes some way toward supplying continuity in care, it is as such not sufficient. Communication conducted exclusively via phoning and Skype is likely to distort relationships, especially in their emotional dimension, as some studies on migrant children suggest (Lutz and Palenga-Mollenbeck 2012).

7. Depending on how far the parents migrate and what kind of contracts they have, the separation varies from a few months to a few years at a time. For instance, women who migrate to the neighboring country within Europe often engage in rotational migration: they work for three months in the destination country, then return home for a few months and then leave again. By contrast, migrants from Mexico or the Philippines are sometimes unable to return home more often than every few years (Lutz and Palenga-Mollenbeck 20I2).

8. The total number of Romanian minors who had at least one parent working abroad at the end of 2006 was 60,000, of which 21,400 were living without any of their parents.

9. I offer a more detailed analysis of the harms of care drain in the case of Romanian children and their immediate and extended families in Gheaus (2013a).

Io. Some authors argue that women's migration is essentially a middle-class phenomenon (Lutz and Palenga-Mollenbeck 20I2) and that migrants are often driven by a desire for upward social mobility (Ottonelli and Torresi, forthcoming). In various social circumstances-depending on the kind of social security one enjoys and the level of corruption and thus unpredictably that characterizes one's society—being middle-class or seeking upward mobility may or may not be a voluntary choice in the sense of voluntariness defined above.

\section{References}

Alstott, Anne. 2004. No Exit: What Parents Owe Their Children and What Society Owes Parents. Oxford: Oxford University Press.

Archard, David. 2010. "The Obligations and Responsibilities of Parenthood." In Procreation and Parenthood. Edited by David Archard and David Benatar, 103-27. Oxford: Oxford University Press.

Asociatia Alternative Sociale (AAS). 2006. Singur Acasa! Studiu efectuat in zona Iasi asupra copiilor separati de unul sau ambii parinti prin plecarea acestora la munca in strainatate. Iasi: Asociatia Alternative Sociale.

Blake, Michael. 2005. "International Justice." In Stanford Encyclopedia of Philosophy, http://plato.stanford.edu/entries/international-justice/. 
Blustein, Jeffrey. 1982. Parents and Children: The Ethics of the Family. Oxford: Oxford University Press.

Brennan, Samantha, and Bill Cameron. n.d. Unpublished manuscript. "How Many Parents Can a Child Have? Philosophical Reflections on the 'Three Parent Case."

Brighouse, Harry, and Adam Swift. 2006. "Parents' Rights and the Value of the Family." Ethics $117: 80-108$.

Clayton, Matthew. 2006. Justice and Legitimacy in Upbringing. Oxford: Oxford University Press.

Cutas, Daniela. 20Ir. "On Triparenting: Is Having Three Committed Parents Better Than Having Only Two?” Journal of Medical Ethics 37 (I2): 735-38.

Dayton-Johnson, Jeff, Louka T. Katseli, Anna di Mattia, and Theodora Xenogiani. 2007. Policy Coherence for Development: Migration and Developing Countries. Paris: OECD Development Centre.

Dobre, Suzana. 2009. "The Romanian Welfare State: Changing and Developing." In The Handbook of European Welfare Systems. Edited by Klaus Schubert, Simon Hegelich, and Ursula Bazant, 415-27. London and New York: Routledge.

Dumitru, Speranta. 201r. "Care Drain: Le piege sexiste du nationalisme." In WorldWideWomen: Globalizzazione, Generi, Linguaggi, vol. 3. Edited by T. Caponio, F. Giordano, B. Manetti, and L. Ricaldone, 5I-60. Turin: Centro Interdisciplinare di Ricerche e Studi delle Donne.

Engster, Daniel. 2008. The Heart of Justice: Care Ethics and Political Theory. Oxford: Oxford University Press.

Farooq, Muhammad, and Zahoor Hussain Javed. 2009. "The Impact of International Migration on Migrants' Families Left Behind in the Rural Area of Pakistan." Pakistani Journal of Agricultural Science 46 (4): 233-36.

Frehywot, Seble, Fitzhugh Mullan, Perry W. Payne, and Heather Ross. 2010. "Compulsory Service Programmes for Recruiting Health Workers in Remote and Rural Areas: Do They Work?" Bulletin of the World Health Organization 88 (5):364-70. Gheaus, Anca. 2013a. "Care Drain: Who Should Provide for the Children Left Behind?" Critical Review of International Social and Political Philosophy I6 (I): I-23.

-2013b. "Care Drain as an Issue of Global Gender Justice." Ethical Perspectives $20(\mathrm{I}): 6 \mathrm{I}-8 \mathrm{O}$.

Goodin, Robert. 1985. Protecting the Vulnerable. Chicago: Chicago University Press.

Hamburg Institute of International Economics (HIIE). 2007. Focus Migration: Country Profile Romania. Hamburg: Hamburg Institute of International Economics.

Helm, Bennett. 2010. Love, Friendship and the Self: Intimacy, Identification, and the Social Nature of Persons. Oxford: Oxford University Press.

Hochschild, Arlie. Russel. 2005. "Love and Gold.” In Luciana Ricciutelli, Angela Miles and Margaret H.McFadden. London: Zed and Toronto, ON: Innana, 34-46.

Hochschild, Arlie Russell. 2000. "Global Care Chains and Emotional Surplus Value." In On the Edge: Living with Global Capitalism. Edited by A. Giddens and W. Hutton, 130-46. London: Jonathan Cape. 
Isaksen, L., U. Devi, and A. Hochschild. (2008). "Global Care Crisis: A Problem of Capital, Care Chain, or Commons?” American Behavioral Scientist 52 (3): 405-25.

Jordan, Lucy, and Elspeth Graham. 2012. "Resilience and Well-Being Among Children of Migrant Parents in South-East Asia." Child Development 83 (5): 1672-88.

Kandel, William. 2003. "The Impact of U.S. Migration on Mexican Children's Educational Attainment." In Education, Family and Population Dynamics. Edited by Maria Cosio, Richard Marcoux, Marc Pilon, and Andre Quesnel, 305-28. Paris: CICRED.

Lutz, Helma, and Ewa Palenga-Mollenbeck. 2012. "Care Workers, Care Drain, and Care Chains: Reflections on Care, Migration, and Citizenship." Social Politics I9 (I): $15-37$.

Macleod, Colin. 2013. "Parental Competency and the Right to Parent." Paper presented during the "Permissible Progeny" conference, University of West Ontario, London, Ont., June 29-30.

Morrison, Andrew R., Maurice Schiff, and Mirja Sjöblom. 2008. The International Migration of Women. Washington, D.C.: The World Bank.

Munoz-Darde, Veronique. 1999. "Is the Family to Be Abolished Then?" Proceedings of the Aristotelian Society 99:37-56.

Narveson, Jan. 2002. Respecting Persons in Theory and Practice. Lanham, Md.: Rowman \& Littlefield.

Olsaretti, Serena. 2004. Liberty, Desert and the Market. Cambridge: Cambridge University Press.

-2008. "Debate: The Concept of Voluntariness-a Reply." Journal of Political Philosophy 16:112-21.

Ottonelli, Valeria, and Tiziana Torresi. Forthcoming. "Temporary Migration and the Shortcomings of Citizenship: The Case of Female Circular Migration from Romania to Italy." In Impact of Circular Migration on Human, Political and Civic Rights. A Global Perspective. Edited by Solé, C., Parella, S., Sordé, T. and Nita, S., Springer.

Pantea, Maria. 2012. "Grandmothers as Main Caregivers in the Context of Parental Migration." European Journal of Social Work I5 (I): 63-80.

-.2013. "Negotiating 'Children's Best Interests' in the Context of Parental Migration." In Trust Dynamics in the Governance of Children and Youth - a European

AQ:1 Perspective. Edited by Hanne Warming, xx-xx. Basingstoke: Palgrave Macmillan.

Piperno, Flavia. 2007a. "From Care Drain to Care Gain: Migration in Romania and Ukraine and the Rise of Transnational Welfare," Development 50 (4): 63-68.

$-2007 \mathrm{~b}$. "L'altra faccia del nostro welfare: Il drenaggio di cura nei paesi di origine. Il caso della Romania," Studi Emigrazione/Migration Studies 44 (I68): 94767 .

-2007c. "Welfare for Whom? The Impact of Care Drain in Romania and Ukraine and the Rise of a Transnational Welfare." CeSPI. Available online: http:// www.cespi.it/PDF/piperno-welfare.pdf (accessed on February 28, 2014). 
Qin, Jiang, and Björn Albin. 2010. "The Mental Health of Children Left Behind in

Rural China by Migrating Parents: A Literature Review." Journal of Public Mental Health 9 (3): 4-16.

Rawls, John. 1972. A Theory of Justice. Oxford: Oxford University Press.

Shiffrin, Seana. 1991. "Moral Autonomy and Agent-centred Options." Analysis 51:244-54. _ 1999. "Wrongful Life Procreative Responsibility and the Significance of Harm." Legal Theory 5:117-48.

Soros Foundation Romania (SFR). 2007. Efectele migratiei: Copii ramasi acasa. Bucharest: Soros Foundation Romania.

-2012. Efectele migratiei asupra copiilor ramasi acasa. Motivatie audiere publica. Bucharest: Soros Foundation Romania.

Stanczyc, Lucas. 2012. "Productive justice." Philosophy and Public Affairs 40 (2): 144-64. Tronto, Joan. 1993. Moral Boundaries: A Political Argument for an Ethic of Care. New York: Routledge.

UNICEF and Asociatia Alternative Sociale (AAS). 2008. Analiza la nivel national asupra fenomenului copiilor ramasi acasa prin plecarea parintilor la munca in strainatate. Iasi: Asociatia Alternative Sociale.

Waldfogel, Jane. 2006. What Children Need. Cambridge, Mass.: Harvard University Press.

Wolff, Johnathan, and Avner De-Shalit. 2007. Disadvantage. Oxford: Oxford University Press.

United Nations. 1989. The United Nations Convention on the Rights of the Child Available online: http://www.unicef.org.uk/Documents/Publication-pdfs/UNCRC_ PRESS200910web.pdf (accessed February 28, 2014).

\section{Author Query}

AQ 1: Please provide the page numbers on which this chapter is located. 